\title{
Analysis of the Effectiveness of School Educational Managers' Activity at Different Career Stages
}

\author{
Svetlana Koshevenko \\ Department of Management \\ Smolensk State University \\ Smolensk, Russia \\ E-mail:svk79home@mail.ru
}

\author{
Svetlana Silchenkova \\ Department of Economics \\ Smolensk State University \\ Smolensk, Russia \\ E-mail: sil-sv@mail.ru
}

\begin{abstract}
The article is dedicated to the problem of the effectiveness of school educational managers' activity. The dependence of effectiveness indexes on the career stage is analyzed. The analysis data were received as a result of school monitoring in Smolensk region in 2016.
\end{abstract}

Keywords-efficiency of activities; educational manager; school; educational organization; the director of the school; the head teacher of the school

\section{INTRODUCTION}

For every organization, personnel are the most complex management subject as in contrast with other types of resources it is able to critically assess and give subjective estimations of manager's actions, react against influence, study own interests. Furthermore, performance effectiveness of the organization itself depends on the effectiveness of human resources management. At factories and organizations with a hierarchical corporate pattern, separate HR departments and services are created in order to manage staff and its development.

The theory of lifelong learning is becoming more and more popular over the recent years, the key aim of which is to develop the educational potential of a person throughout his or her life $[6 ; 8 ; 9]$. In different types of organizations, the concept of HR management is also changing. Today the formation of "learning organizations" is taking place that creates the necessary conditions and facilitates lifelong learning for the staff $[11,13,14]$.

The problem of educational personnel development is one of the most topical on the stage of transformation to the information society, as education is the generation sphere of new knowledge and information. To our mind, educational organizations cannot contribute to an intensive development of the intellectual, social and economic potential of a country in case they haven't acquired the status of a "learning organization".

HR development in a comprehensive educational organization is the task of principals, deputy principals, heads of school methodological communities, methodologists. All of them perform the functions of educational managers: select and arrange teaching staff, manage the process of employees' adaptation, cooperate with the teachers regarding questions of organizing their educational path and course of career progress, plan and organize staff training according to the organizational goals with respect to the employees' interests, fulfill informationalmethodological and informational-pedagogical support of teachers. The effectiveness of this activity influences the effectiveness of "learning organization" formation, staff development, innovation and increase in workforce capacity. The problem lies in the absence of a universal methodology for effectiveness assessment of such activity of educational managers and studied factors influencing this activity.

We have already developed a system of key effectiveness indicators of school educational managers and conducted an analysis showing the influence of the informational culture of educational managers on this system (Koshevenko S.V., Silchenkova S.V., 2015, 2016). The aim of this study is to assess and analyze the effectiveness of school educational managers (EM) activity at different stages of their career.

\section{MATERIALS AND METHODS}

Methodological basis of the study accounts for the scientific works in the sphere of:

- educational management (T. Boydell, J. Bourgoin, B. Guetl, Ivanova E.V., Ortey F., Pevzner M.N., Pedler M., Petryakova P.A., Fedotova G.A., Fosket N., Sheraizina R.M., Shirin A.G., etc.) $[1,2,3,12]$. A number of scientists from Yaroslav-the-Wise Novgorod State University point at the necessity of formation of readiness for "innovative activity, assuring the development of learning organizations on the basis of knowledge management concept and reflection of personal and professional development..." by an educational manager [12, p. 334];

- HR management (I.A. Epeshkin, A.Y. Kibanov, L.I. Lukicheva, etc.). The most topical for our study is the approach to the effectiveness assessment of HR work $[5 ; 7 ; 10]$. I.A. Epeshkin divides these indicators into three groups (financial, management and personnel loyalty and satisfaction indicators) and marks out separate indicators which can be considered as 
effectiveness indexes of the activity in this sphere [5, p. 123];

- educational systems management (Artyukhov M.V., Kapustin N.P., Tretyakov P.I., Shamova T.I.) [4; 15]. Thus, Shamova T.I., Tretyakov P.I. and Kapustin N.P. distinguish the following items as analysis blocks of school principal's activity: informational-analytical, planning-predicting, control-diagnostic and correctional skills together with the effectiveness of organizational-performing activity $[15$, p. 89$]$. As the functions of educational managers in school are assigned to the principal, deputy principals and heads of school methodological communities, then the effectiveness of their activity in the sphere of $\mathrm{HR}$ management can be analyzed and assessed on the basis of the marked blocks.

Based on the works of the above-mentioned authors, we have developed a system of key effectiveness indicators of school EM activity. Nine blocks are marked for the assessment and for each block there are key effectiveness indicators (indicators) and assessment criteria "Fig. 1".
It is possible to get acquainted with this methodology and develop diagnostic materials in more detail in the previous works of the authors of the current article (Koshevenko S.V., Silchenkova S.V., 2015, 2016).

In 2016, the monitoring of principals and deputy principals of schools in Smolensk region regarding the issue of educational managers' effectiveness was conducted with the support of Smolensk regional Department for education, science, and youth affairs. 116 respondents from 64 city schools and district centers schools and 159 respondents from 118 village schools of Smolensk region (275 respondents in total) took part in the mentioned monitoring. Such sample volume is considered enough for monographic research. Reliability and validity of the test are confirmed with the value of Cronbach alpha coefficient $(0,88)$.

In order to achieve the stated goal, we have used such research methods as studying scientific literature related to the research problem, system analysis, polling with the help of questionnaire survey, statistical data analysis, graphical and tabular methods and factor analysis.

\begin{tabular}{|c|c|c|c|c|c|c|}
\hline \multicolumn{7}{|c|}{ Blocks and effectiveness indicators of school educational managers' activity } \\
\hline \multicolumn{7}{|c|}{ Block 1. Selection and adaptation of new employees } \\
\hline \multicolumn{2}{|l|}{ personnel staffing } & \multicolumn{3}{|c|}{$\begin{array}{c}\text { adjustment of a new employee to } \\
\text { working conditions in an educational } \\
\text { organization }\end{array}$} & \multicolumn{2}{|c|}{$\begin{array}{l}\text { satisfaction of new employees } \\
\text { with support and working } \\
\text { conditions }\end{array}$} \\
\hline \multicolumn{7}{|c|}{ Block 2. Designing of individual educational paths of teachers } \\
\hline \multicolumn{3}{|c|}{$\begin{array}{l}\text { number of teachers for whom an individual } \\
\text { educational path has already been designed }\end{array}$} & \multicolumn{4}{|c|}{$\begin{array}{c}\text { accordance of a designed educa } \\
\text { teacher's goals and aims of ar } \\
\text { organization }\end{array}$} \\
\hline \multicolumn{7}{|c|}{ Block 3. Staff training organization (within } \\
\hline \begin{tabular}{|c|} 
number of teachers who \\
have passed advanced \\
training and retraining in a \\
timely manner \\
\end{tabular} & \multicolumn{2}{|c|}{$\begin{array}{l}\text { accordance of training with } \\
\text { the disciplines taught and } \\
\text { teachers' demands }\end{array}$} & \multicolumn{3}{|c|}{$\begin{array}{c}\text { satisfaction of teachers with } \\
\text { the conducted in-house } \\
\text { training }\end{array}$} & $\begin{array}{c}\text { readiness of employees to } \\
\text { use new technologies and } \\
\text { knowledge }\end{array}$ \\
\hline \multicolumn{7}{|c|}{ Block 4. Designing of individual courses of teachers' career progress } \\
\hline \multicolumn{2}{|c|}{$\log$ (annual plan) of career promotion } & \multicolumn{2}{|c|}{$\begin{array}{l}\text { positions substituted through inner } \\
\text { employees shifting }\end{array}$} & \multicolumn{3}{|c|}{$\begin{array}{c}\text { number of teachers who have acquired I } \\
\text { or higher qualification grade with an } \\
\text { active informational-pedagogical } \\
\text { support of the EM }\end{array}$} \\
\hline \multicolumn{7}{|c|}{ Block 5. Building of the system of cooperation with teaching staff } \\
\hline \multicolumn{3}{|c|}{ fulfilled functional tasks } & \\
\hline \multicolumn{3}{|c|}{$\begin{array}{c}\text { Block 6. Creation and coordination of project groups' work and coordination of teacher's individual research } \\
\text { work }\end{array}$} & & & & \\
\hline \multicolumn{3}{|c|}{$\begin{array}{l}\text { number of applications from teaching staff for participation } \\
\text { in grants, professional skill competitions }\end{array}$} & \multicolumn{4}{|c|}{$\begin{array}{l}\text { number of winners and awardees of competitions of } \\
\text { different levels, grants awarded }\end{array}$} \\
\hline \multicolumn{7}{|c|}{ Block 7. Employees database maintenance } \\
\hline \multicolumn{3}{|c|}{ the fullness of employees database maintenance } & \multicolumn{4}{|c|}{ the speed of background reports and records drafting } \\
\hline \multicolumn{7}{|c|}{ Block 8. Public relations } \\
\hline \multicolumn{2}{|c|}{$\begin{array}{l}\text { participation in different events } \\
\text { conducted within a school }\end{array}$} & \multicolumn{3}{|c|}{$\begin{array}{c}\text { cooperation with external organizations, } \\
\text { social partnership }\end{array}$} & \multicolumn{2}{|r|}{ relations with media } \\
\hline \multicolumn{7}{|c|}{ Block 9. Outreach activity of an educational manager } \\
\hline \begin{tabular}{|c|} 
participation in seminars, \\
conferences, advanced \\
training courses regarding \\
EM field of activity \\
\end{tabular} & \multicolumn{2}{|c|}{$\begin{array}{c}\text { sharing of experience through } \\
\text { participation in professional } \\
\text { skill competitions }\end{array}$} & \multicolumn{3}{|c|}{$\begin{array}{c}\text { participation in } \\
\text { experimental (research) } \\
\text { work }\end{array}$} & publication activity \\
\hline
\end{tabular}

Fig. 1. Key effectiveness indicators of EM's activity 


\section{RESEARCH RESULTS}

The analysis of the received data should be started from checking the average effectiveness indicators of school EMs' activity in Smolensk region. The average questionnaire score is 2,63 which shows the medium effectiveness of EMs in the region on the whole. The average indicators of effectiveness blocks are given in "Fig. 2".

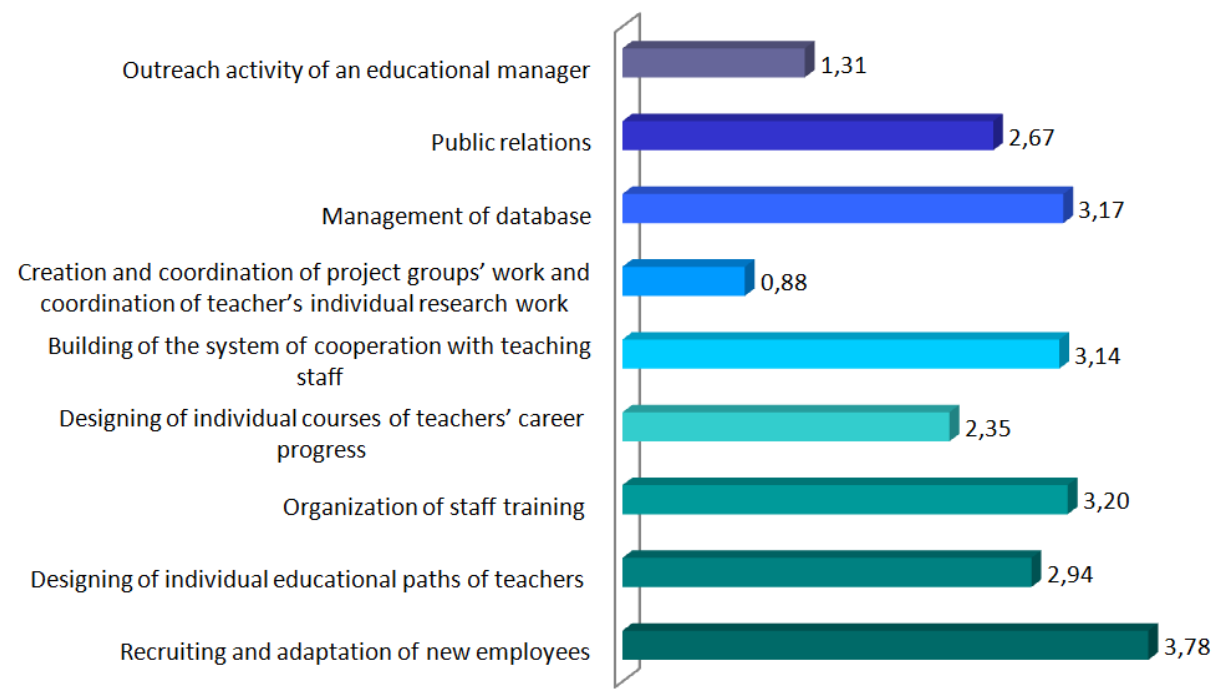

Fig. 2. Average effectiveness indicators of educational managers in Smolensk region according to the blocks.

As seen from the given diagram, educational managers showed a rather low score in several blocks (outreach activity of EM is 1,31; creation and coordination of project groups' work and coordination of teacher's individual research work is 0,88), that shows the insufficient effectiveness of their work in these spheres. Further, we should examine whether these low scores in the above-stated blocks are revealed at different stages of career progress.

"Table I" reveals the characteristics of career stages that are universal for every field of work and profession. [7]

TABLE I. CHARACTERIZATION OF CAREER STAGES

\begin{tabular}{|c|l|l|l|}
\hline Career stage & Age period & \multicolumn{1}{|c|}{$\begin{array}{c}\text { Brief characterization } \\
\text { (according to Maslow) }\end{array}$} \\
\hline Preliminary & Up to 25 years & Preparation for labor activity, choice of field of work & Safety, social acknowledgment \\
\hline Formation & Up to 30 years & $\begin{array}{l}\text { Profession and skills acquisition, formation of a qualified } \\
\text { specialist or manager }\end{array}$ & $\begin{array}{l}\text { Social } \\
\text { independence }\end{array}$ \\
\hline Promotion & Up to 45 years & $\begin{array}{l}\text { Professional development: improvement of skills, } \\
\text { experience gaining, promotion }\end{array}$ & $\begin{array}{l}\text { Social acknowledgment, self- } \\
\text { realization }\end{array}$ \\
\hline Preservation & Up to 60 years & $\begin{array}{l}\text { Securing of the achieved results. The climax of } \\
\text { qualification development, its upgrade } \\
\text { professional activity and youth training. Creative work }\end{array}$ & $\begin{array}{l}\text { Pay rise, new sources of income. } \\
\text { The highest degree of independence } \\
\text { and self-expression. Respect }\end{array}$ \\
\hline Ending & Up to 65 years & $\begin{array}{l}\text { Preparation for retiring, search and training of the next } \\
\text { generation of workers }\end{array}$ & Securing of social acknowledgment \\
\hline Retiring & After 65 years & Moving to some other activities & $\begin{array}{l}\text { Search of self-expression in a new } \\
\text { field of activity }\end{array}$ \\
\hline
\end{tabular}

In order to achieve the research goal, the whole sample was divided into several groups according to age that corresponds to each career stage. As there are no respondents under 25 years in the sample, the number of groups accounts for 5. The quantity of surveyed persons in each group is not equal. Thus, the number of educational managers at the age from 26 to 30 in the region accounts for only 2 persons; their average working experience is 3 years. 78 respondents were surveyed at the age from 31 to 45; their average working experience accounts for 6 years. The next age group that corresponds to preservation career stage (from 46 to 60 years) is the most numerous - 161 persons with the average working experience of 13 years. The group of ending career stage (from 61 to 65 years) consists of 23 persons with the average working experience of 25 years. Also, there are 10 respondents at the age of 65 and older with the average working experience of 29 years. The maximum age accounts for 70 years.

On the whole, this grouping reflects practically all stages of career development: at a young age (up to 30 years) specialists learn, gaining first working experience and not being able to perform the duty of an educational manager to the full extent, at a retirement age (older than 65 years) educational managers should keep up with the times in order to fulfill the duties and this is not always possible, thus, such respondents are in the minority. 
The average effectiveness grade of educational manager's activity has been calculated for each group of surveyed both overall and for each block of indicators functional tasks of educational managers "Table II".

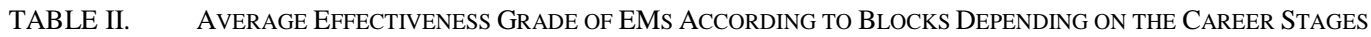

\begin{tabular}{|c|c|c|c|c|c|}
\hline \multirow[b]{2}{*}{ The functional task of a school educational manager } & \multicolumn{5}{|c|}{ Career stage } \\
\hline & $\begin{array}{c}\text { Formation } \\
\text { (up to } 30 \text { years) }\end{array}$ & $\begin{array}{c}\text { Promotion } \\
\text { (up to } 45 \text { years) }\end{array}$ & $\begin{array}{c}\text { Preservation } \\
\text { (up to } 60 \text { years) }\end{array}$ & $\begin{array}{c}\text { Ending } \\
\text { (up to } 65 \text { years) }\end{array}$ & $\begin{array}{c}\text { Retiring } \\
\text { (after } 65 \text { years) }\end{array}$ \\
\hline Recruiting and adaptation of new employees & 3,42 & 3,97 & 3,88 & 3,75 & 3,98 \\
\hline Designing of individual educational paths of teachers & 3,67 & 3,17 & 2,88 & 3,03 & 2,77 \\
\hline Organization of staff training & 3,00 & 3,57 & 3,03 & 3,22 & 2,92 \\
\hline Designing of individual courses of teachers' career progress & 3,17 & 2,58 & 2,24 & 2,12 & 2,00 \\
\hline Building of the system of cooperation with teaching staff & 3,50 & 3,49 & 3,02 & 3,01 & 2,95 \\
\hline $\begin{array}{l}\text { Creation and coordination of project groups' work and } \\
\text { coordination of teacher's individual research work }\end{array}$ & 0,92 & 1,52 & 0,80 & 0,91 & 0,80 \\
\hline Management of database & 3,33 & 3,39 & 3,12 & 3,05 & 2,33 \\
\hline Public relations & 1,67 & 2,83 & 2,43 & 2,31 & 2,40 \\
\hline Outreach activity of an educational manager & 0,38 & 1,67 & 1,12 & 1,56 & 1,12 \\
\hline Total average point & 2,56 & 2,91 & 2,50 & 2,70 & 2,36 \\
\hline
\end{tabular}

If we consider the whole trend of the overall effectiveness indicator of EM's activity, we see its increase at the stage of career promotion (age from 31 to 45 years) up to the score of 2,91 , some decrease (down to 2,5 or $14 \%$ in comparison with the previous stage) at the stage of preservation, then another increase up to 2,7 at the stage of career ending and further decrease (down to 2,36 or $19 \%$ in comparison with maximum value) at the retiring stage (older than 65 years). While examining effectiveness blocks of EM's activity, we can see maximum values of indicators also for promotion stage.

Rather predictable is a high score of EMs who are on the promotion stage as these specialists are considered to apply utmost efforts in work, be active in professional life, have growing qualification level, gain experience, and get promotions; they are eager to receive recognition in the staff and self-actualize.

An increase in overall effectiveness indicator of EM at the age from 61 to 65 (ending stage) in comparison with preservation stage can be explained through an increase in employees' activity, they sort of prove to themselves and their younger colleagues that they have enough experience and can do much even at this age.

Though the first and the last groups of respondents cannot be considered statistically relevant, it is characteristic that the minimal score is shown by seniors (older than 65 years) and not by their young and inexperienced colleagues at the age of 30 who are more motivated to achieve high results in professional activity.

Let's consider what problems can be marked out for each stage of career development.

For the group of educational managers at the stage of career formation, we can distinguish the lowest effectiveness level in comparison with the other respondent groups in the blocks "Public relations" and "Outreach activity of an educational manager". Lack of experience, huge time expenditures on fulfilling current administrative, economic and pedagogical duties prevent a manager from organizing conferences, seminars, master-classes and taking part in them as well as increasing publication activity. Nevertheless, young age gives advantages in using progressive knowledge and leading experience and low scores in positions "Participation of an educational manager in professional skill competitions" and "Participation of an educational manager in experimental work" are the indicator of the insufficient possible effectiveness of their activity. As to public relations, the school management is not interested in this issue and the media are interested only in the most active and talented young managers who can transfer progressive experience of their educational organization.

At the promotion stage, we see rather low indicators in the blocks "Designing of individual educational paths of teachers" and "Designing of individual courses of teachers' career progress". They are lower than the same indicators at formation stage group. This suggests that EMs at the age from 31 to 45 don't pay enough attention to the career development and education of employees of an educational organization.

Average grades for almost all effectiveness blocks at the preservation stage are lower than the relevant EM grades at formation and promotion stages. Once EMs achieve the targeted level of independence and self-development as well as acquire the desired respect and recognition, many of them are likely to become less active assuming that they no longer need to prove their abilities or to strive to reach better results expecting their image to do that for them. As a result, such critical aspects of their activity as sharing the professional experience, assisting new employees in their integration into the community, supervising teachers in their research activity and career development are not prioritized by employees beyond 60, what has an adverse effect on the effectiveness of young specialists. This might be viewed in average scores for such blocks as "Designing of individual educational paths of teachers," "Designing of individual courses of teachers' career progress," "Building of the system of cooperation with teaching staff," and "Creation and coordination of project groups' work and coordination of teacher's individual research work." The scores for these blocks are lower at the preservation stage than those at preceding stages. 


\section{REFERENCES}

At the retiring stage, some effectiveness indicators of EM's activity are higher than those at other stages of career development which is determined by such factor as professional experience. The most problematic aspects of activity are those associated with the data management, project group formation, and coordination as well as the supervision of a teacher's research activity. Low scores in these blocks reflect the poor informational culture of managers of "retirement age" and lack of motivation for implementing new technologies and innovative ideas.

In the meantime, each stage of career development implies its own prospects for self-realization. Thus, for instance, young managers put a larger emphasis on assisting employees in their career development regarding this aspect of their activity as a priority. More experienced EMs, in their turn, show higher effectiveness in recruitment processes. Their professional experience and intuition allow them to evaluate applicants' competency as well as to assist them during the adaptation period.

\section{CONCLUSION}

Thus, the analysis of the educational managers' effectiveness carried out at different stages of career development in Smolensk region has helped to reveal a series of operation-related flaws that have an adverse effect on the activity effectiveness.

Once being at the first stages of the career development, educational managers prove to have poorly formed public relation and outreach activity skills. At the promotion stage, educational managers pay insufficient attention to the development of employees in educational organizations. Likewise, educational managers are not involved in sharing the experience with younger generations, ensuring their integration into the educational environment, supervising their research activity, and assisting them all the way long their career development, which influences the effectiveness indicators negatively. At the retiring stage of the career development, managers exhibit a low level of information culture, the lack of motivation for implementing new technologies and progressive ideas.

The present analysis has helped to define the major milestones in the growth of the educational managers' effectiveness at each stage of their career development. It is essential to design the advanced training programs for principal and deputy principals in Smolensk schools in accordance with the stage of career development, forming the educational groups, selecting the educational programs and teaching methods adequate to the relevant stage.

This work needs to be approached with detailed elaboration and critical analysis of the data from other regions since different groups in Smolensk schools have diverse characteristics at each stage of career development.
[1] Foskett, N., Lumby J.,. Leading and Managing Education: International Dimensions, London, Paul Chapman Publishing, 2003, p. 240.

[2] Gütl B., Orthey F.M., Laske S., Bildungsmanagement. München und Mering, 2006. p. 246.

[3] Pedler M., Burgoyne J., Boydell T. The Learning Company. The MacGraw-Hill Books, 1997, p. 243.

[4] Artyukhov M.V., Educational systems management: management, marketing, human resources, Novokuznetsk, 2004, p. 269.

[5] Epishkin I.A., Human resources management, Textbook for bachelors of the program 080200 "Management", M.: MPT, 2013, p. 157

[6] Zaitseva O.V., Continous education: general concepts and definitions, TGPU Reporter, 2009, No.8, pp. 106-109. URL: http://cyberleninka.ru/article/n/nepreryvnoe-obrazovanie-osnovnyeponyatiya-i-opredeleniya (accessed date 23.02.2017).

[7] Kibanov A.Ya., Human resources: textbook / A.Ya. Kibanov, G.P Gagarinskaya, O.Yu. Kalmykova, E.V. Muller, M: INFRA-M, 2013, p. 238.

[8] Kolesnikov N.E.6 Professional development as the form of continuous professional education and the priority of human resources modernization in economy // Learning throughout life: continuous education for benefit of sustainable growth, 2010, URL: http://cyberleninka.ru/article/n/perepodgotovka-kadrov-kak-formanepreryvnogo-professionalnogo-obrazovaniya-i-vazhnoe-napravleniemodernizatsii-kadrovogo-resursa (accessed date: 23.02.2017)

[9] The concept of adults' continuous education in the Russian Federation for the period until the year 2025 [Electronic resource], URL: www.irdpo.ru/concept.html (accessed date: 23.02.2017).

[10] Lukicheva L.I., Human resource management: Textbook, M.: Omega-L, 2013, p. 263.

[11] Nesterov O.V., Human resource training as an organization's strategic objectives achievement tool // Online magazine Naukovedenie, 2015 Vol.7, No.2. URL: http://naukovedenie.ru/PDF/09EVN215.pdf (accessed date: 22.02.2017).

[12] Learning management: textbook for graduate courses in Pedagogy / Ye.V. Ivanov, M.N. Pevzner, P.A. Petryakov, G.A. Fedotova, R.M. Shcheraizina, A.G. Shirin / authored and edited by E.V. Ivanova, M.N. Pevzner, Veliky Novgorod: Nizhny Novgorod Yaroslav Mudry University, 2010, p. 412.

[13] V. Pushnykh, "Learning" organizations and universities, Higher Education in Russia, 2004, No. 11, pp. 118-127.

[14] Senge P.M., Forming-up of the learning organization// SPbGU Reporter, 2004, Series8, Issue 1 (No.8).

[15] Shamova T.I., Tretiakov P.I., Kapustin N.P., Educational systems management: Textbook for college students, M.: Humanitarian publishing center VLADOS, 2002, p. 320. 